\title{
A Net-planting Technique for Establishing Zoysiagrass from Sprigs
}

\author{
M.D. Richardson, ${ }^{1}$ \\ J.W. Boyd, ${ }^{2}$ and J.H. McCalla ${ }^{1}$
}

Additional IndeX words. zoysia, stolons, turfgrass, sod, propagation

SummarY. Zoysiagass (Zoysia japonica) use continues to expand on golf courses, home lawns, and sports fields in the transition zone. Unfortunately, the slow growth rate of the species and long establishment period have limited its use to those sites that can afford zoysiagrass sod. The development of sprig-planting techniques that can produce a zoysiagrass turf in a single season would considerably increase the use of this desirable species. A study was conducted over 2 years at two different regions in Arkansas to evaluate the efficacy of a new zoysiagrass net-planting technique (ZNET) on establishment of zoysiagrass from vegetative sprigs. The technique involves rolling the sprigs onto the site in cotton netting and top-dressing the sprigs with $\mathbf{1 . 0}$ $\mathrm{cm}(0.4 \mathrm{inch})$ of native soil. This technique was compared to a standard sprig-planting technique and a standard sprig planting that was also top-dressed with $1.0 \mathrm{~cm}$ of native soil. The standard treatments were planted according to established methods using freshly-harvested sprigs applied at a rate of $70.0 \mathrm{~m}^{3} \cdot \mathrm{ha}^{-1}$ [ 800 bushels $\left(1000 \mathrm{ft}^{3}\right)$ per acre]. Rate of turfgrass cover was monitored throughout the growing season. The ZNET planting technique significantly improved establishment over the traditional sprigging technique and the turf reached about $85 \%$ cover by the end of the growing season (120 days). Top-dressing a traditionally sprigged area with native soil also improved

We acknowledge the technical support of E. Bordeleon and B. Rodgers and the financial support of Winrock Grass Farms.

${ }^{1}$ Associate Professor and Research Specialist, respectively, Department of Horticulture, University of Arkansas, Fayetteville, Ark 72701

${ }^{2}$ Extension Specialist, Cooperative Extension Service, University of Arkansas, Fayetteville, Ark 72701. 
establishment compared to traditional sprigging and was comparable to the ZNET technique. It was concluded that the ZNET technique did improve establishment rates of zoysiagrass, but the same results could be attained by top-dressing sprigs that were planted with a standard planter.

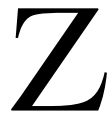
oysiagrass use continues to expand on golf courses, commercial sites, and home lawns throughout the transition zone because of its excellent wear tolerance, winter-hardiness, playability, and overall turf quality of the species. 'Meyer' zoysiagrass, which was introduced into the United States in the 1950s, continues to be the most widely-used zoysiagrass cultivar, although many new cultivars are being introduced (Christians and Engelke, 1994). 'Meyer' must be propagated vegetatively, either by sprigs, plugs, or sod. This cultivar has a very slow growth rate relative to other warm-season grasses and is difficult to establish in most situations (Carrol et al., 1996; Henry et al., 1988). Because of slow establishment, zoysiagrass is often propagated from established sod, which adds substantially to the initial cost.

With the exception of sod, the primary means of establishing 'Meyer' zoysiagrass is to broadcast or rowplant vegetative sprigs at a rate of about $70 \mathrm{~m}^{3} \cdot \mathrm{ha}^{-1}$. Although effective, this method requires 12-18 months from planting to establishment of a complete turf(R. Gravis, personal communication). In golf course or sports field situations, where full cover is generally needed within one season, this is unacceptable. A new vegetative technique of planting zoysiagrass, called ZNET (Winrock Grass Farms, Little Rock, Ark.), was recently described (Miyachi et al., 1993). This method utilizes two layers of biodegradable netting with zoysiagrass sprigs intertwined within the netting. This net/ sprig combination is rolled onto a site in a similar fashion to sod, top-dressed with 6 to $12 \mathrm{~mm}(0.25$ to 0.5 inch $)$ of soil, and watered according to needs. Miyachi et al. (1993) reported that ZNET planting could produce a complete zoysiagrass cover in 85 to $110 \mathrm{~d}$ from planting. Unfortunately, the original study did not compare the ZNET method to traditional sprigging techniques to demonstrate if the method was indeed superior to existing methods. In addition, top-dressing zoysiagrass sprigs with soil has also been shown to significantly improve the establishment rate of zoysiagrass sprigs (Richardson and Boyd, 2001), which may partially explain the advantage of establishing sprigs using the ZNET technique. This study was designed to compare the ZNET planting technique to traditional sprig establishment techniques and to further describe the effects of soil top-dressing on turf establishment rate of 'Meyer' zoysiagrass.

\section{Materials and methods}

Propagation studies were conducted across two geographically distinct regions in Arkansas and across 2 years. The first-year study (1999) was conducted at two sites: Winrock Grass Farms near Little Rock, Ark. [U.S. Dept. of Agriculture (USDA) Hardiness Zone 7, Sallisaw silt loam soil, typic paleudult, $\mathrm{pH}$ 6.7] and the University of Arkansas Research and Extension Center in Fayetteville, Ark. (USDA Hardiness Zone 6, Captina silt loam soil, typic hapludults, $\mathrm{pH}$ $6.2)$. The second-year study (2000) was conducted at the same site in Fayetteville but the central Arkansas site was moved to the Lonoke Research and Extension Center in Lonoke, Ark. (USDA Hardiness Zone 7, Crowley silt loam soil, typic Albaqualfs, $\mathrm{pH}$ 6.3). Each site was fertilized with $112.1 \mathrm{~kg} \cdot \mathrm{ha}^{-1}(100 \mathrm{lb} /$ acre) of $0-20-20(0 \mathrm{~N}-8.7 \mathrm{P}-16.6 \mathrm{~K})$ and prepared to seed-bed quality prior to planting. The planting design and method were identical for both sites and all sites were planted between 15 May and 5 June both years.

The study was arranged as a randomized complete block with four replications. Plot size was $2.4 \times 12.2 \mathrm{~m}$ $(8 \times 40 \mathrm{ft})$ and treatments included 1$)$ traditional sprigging at $70.0 \mathrm{~m}^{3} \cdot \mathrm{ha}^{-1}$, 2) traditional sprigging at $70.0 \mathrm{~m}^{3} \cdot \mathrm{ha}^{-1}$ and top-dressed with $1.0 \mathrm{~cm}$ native soil obtained from the site, and 3 ) ZNET planted and top-dressed with $1.0 \mathrm{~cm}$ native soil obtained from the site. The study also had sub-plots of various nitrogen $(\mathrm{N})$ treatments, which were reported earlier (Richardson and Boyd, 2001). As there was no propagation treatment $\times \mathrm{N}$ interaction, the effects of propagation treatment could be analyzed independently.

To ensure uniform planting densities, the main plots were planted in $2.4 \times 2.4-\mathrm{m}(8-\mathrm{ft})$ increments, using a volume of sprigs obtained by shredding $1.0 \mathrm{~m}^{2}$ (1.20 yard $\left.{ }^{2}\right)$ of 'Meyer' sod. This sprigging rate is based on the definition that 1 bushel $\left[1.25 \mathrm{ft}^{3}(0.035\right.$ $\mathrm{m}^{3}$ ] of sprigs represented those obtained from $0.84 \mathrm{~m}^{2}\left(1.0 \mathrm{yard}^{2}\right)$ of sod (McCarty et al., 1999). Sprigs were uniformly broadcast over the entire plot area, pressed lightly into the soil using a disk, and rolled with a waterfilled roller to smooth the site. The soil used for top-dressing the plots was obtained on-site to prevent soil contamination and screened through a soil sifter [8-mm (0.3-inch) mesh] before application to plots. The soil was uniformly applied with a trackmounted top-dresser. Oxadiazon was applied to all plots at $3.36 \mathrm{~kg} \cdot \mathrm{ha}^{-1}(3.0$ $\mathrm{lb} /$ acre) immediately after planting to suppress weeds, and water was applied as needed during the test to provide optimum growing conditions.

Plots were rated monthly for percentage cover using a grid that separated each main plot into five, $2.4 \times$ $2.4 \mathrm{~m}$ quadrants. Each quadrant was visually rated for percent cover and the five sub-samples from each plot were

Table 1. Analysis of variance testing the effects of year, location, and propagation method on percent turfgrass cover for three evaluation dates.

\begin{tabular}{lrlll}
\hline Source & df & $\mathbf{6 0 D A P}^{\mathbf{z}}$ & $\mathbf{9 0 D A P}$ & $\mathbf{1 2 0 D A P}$ \\
\hline & & & $P>\mathrm{F}$ & \\
Block & 12 & 0.02 & 0.10 & 0.02 \\
Year & 1 & 0.0001 & 0.0001 & 0.0033 \\
Location & 1 & 0.0001 & 0.0001 & 0.02 \\
Year $\times$ location & 1 & 0.0001 & 0.0001 & 0.94 \\
Method & 2 & 0.0001 & 0.0001 & 0.0018 \\
Year $\times$ method & 2 & 0.0043 & 0.0018 & 0.0005 \\
Location $\times$ method & 2 & 0.68 & 0.31 & 0.02 \\
Year $\times$ location $\times$ method & 2 & 0.55 & 0.07 & 0.0015 \\
\hline
\end{tabular}

${ }^{\mathrm{z}} \mathrm{DAP}=$ days after planting 


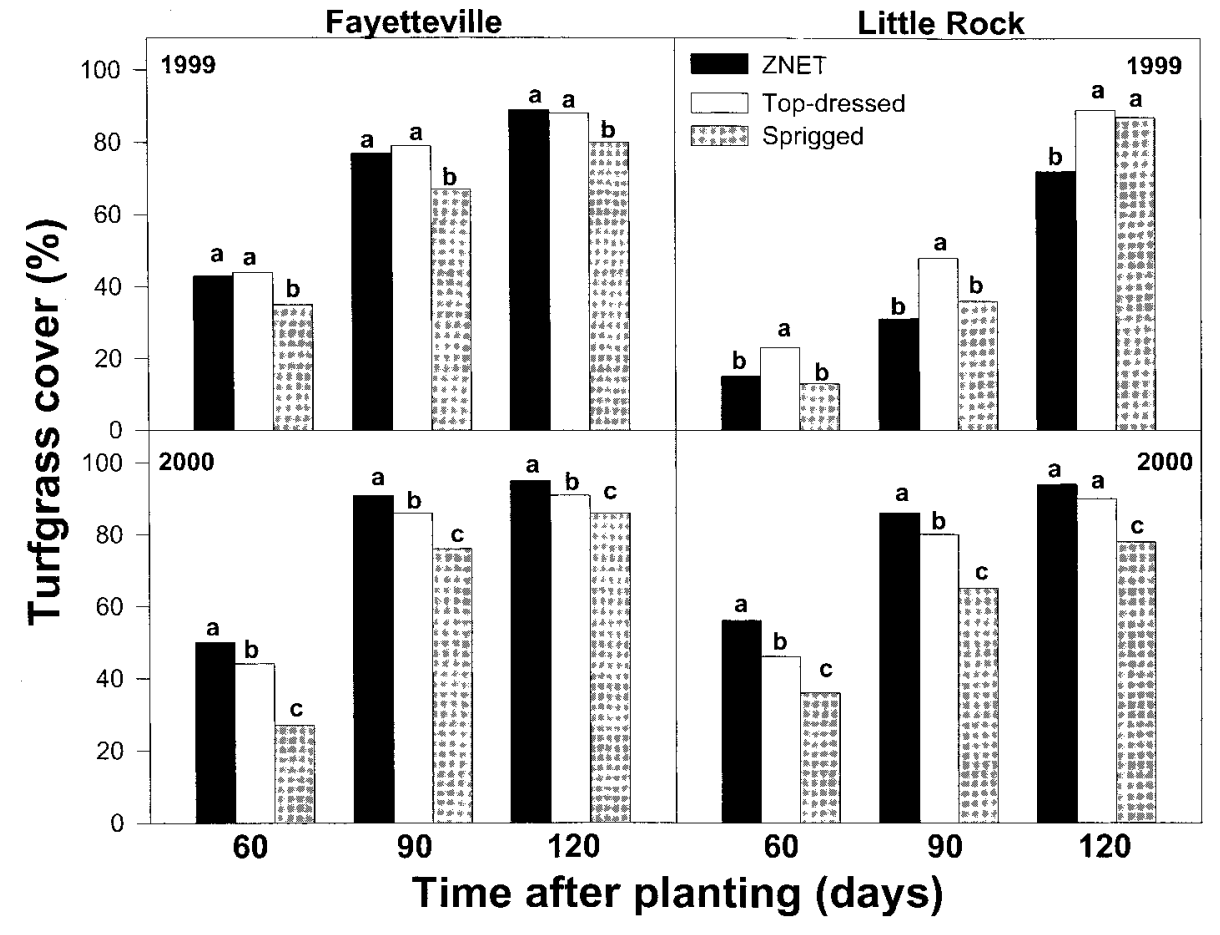

Fig. 1. Zoysiagrass establishment, over two years and two locations, as affected by propagation method. Different letters within a location, year, and evaluation date indicate a significant difference between propagation techniques, as determined by LSD $(P=0.05)$.

averaged for a final cover value. Data from each measurement date were analyzed by analysis of variance procedures using the Statistical Analysis Systems Software (Cary, N.C.).

\section{Results and discussion}

A uniform, weed-free stand was established at all sites with all propagation methods and fertility treatments. A significant year $\times$ location $\times$ treatment interaction was observed (Table 1). Therefore, all subsequent treatment data were analyzed by year and location.

In all tests, the maximum zoysiagrass cover that was reached after 120 d of active growth was between $80 \%$ and $95 \%$. The rate of establishment was influenced by the method of propagation at all locations and across both years (Fig. 1). In general, the ZNET planting method out-performed the traditional sprigging technique at all dates and all sites, except the 1999, Little Rock location. The amount of increase in turfgrass cover due to the ZNET planting technique compared to traditional sprigging was generally around $20 \%$. Although adequate turfgrass cover was attained by the end of the first growing season (120 d after planting), 100\% cover was not attained, as previously reported by
Miyachi et al. (1993). A complete cover in the ZNET plots was not attained until the July of the following growing season, or about 13 months after planting (data not shown).

The effects of top-dressing on sprig establishment rate was similar to the ZNET technique and consistently out-performed the traditionally sprigged turf (Fig. 1). The effect of top-dressing on sprig establishment rate was reported in an earlier study (Richardson and Boyd, 2001) and is further demonstrated in the present research. In two of the test sites, ZNETplanted sprigs established faster than the top-dressed sprigs, but the increased establishment rate was less than $10 \%$ in all cases, which is not economically significant in a field situation. At the other two sites, ZNET did not produce faster establishment rates than top-dressed sprigs and was inferior to top-dressed sprigs in the 1999 Little Rock location.

From these studies, we concluded that one of the primary advantages of the ZNET planting technique was the top-dressing of the sprigs with soil. We observed in all the studies that topdressing sprigs with soil, either in the top-dressed treatments or the ZNET treatments, protected the sprigs from desiccation and provided improved sprig to soil contact, which promoted earlier rooting. Because zoysiagrass sprigs are very slow to initiate growth after harvest, the first few weeks are critical to establishment. Under these circumstances, it is important to protect the sprigs from desiccation until roots are formed and the sprig can extract soil moisture. However, it should be cautioned that the top-dressing depth be maintained at the $1.0-\mathrm{cm}$ depth, as heavy top-dressing of 'Meyer' zoysiagrass may delay emergence and coverage.

Based on the results from these studies, it is difficult to determine an advantage of the ZNET-planting technique over traditional sprigging with the same volume of soil top-dressing. The ZNET planting technique was both labor-intensive and time-consuming, with a maximum planting rate of about $0.4 \mathrm{ha} \cdot \mathrm{d}^{-1}(1 \mathrm{acre} / \mathrm{d})(\mathrm{F}$. Whitbeck, personal communication). As such, the technique may have limited applications to the establishment of golf course fairways. However, this technique may be useful for the establishment of sprigs into sand-based athletic fields and smaller golf areas such as tees or greens.

\section{Literature cited}

Carroll, M.J., P.H. Dernoeden, and J.M. Krouse. 1996. Zoysiagrass establishment from sprigs following application of herbicides, nitrogen, and a biostimulator. HortScience 31:972-975.

Christians, N.E. and M.C. Engelke. 1994. Choosing the right grass to fit the environment, p. 99-113. In: A.R. Leslie (ed.). Handbook of integrated pest management for turfgrass and ornamentals. Lewis Publ., Boca Raton, Fla.

Henry, J.M., S. Tjosvold, and V.A. Gibeault. 1988. Zoysiagrass establishment. Calif. Turfgrass Cult. 38:1-4.

McCarty, B., G. Landry, Jr., J. Higgins, and L. Miller. 1999. Sod production in the southern United States. Clemson Univ. Coop. Ext. Serv. Circ. 702.

Miyachi, Y., F. Yano, H. Tonogi, and Y. Maki. 1993. A newly developed zoysiannet planting system for quick establishment of zoysiagrass. Intl. Turfgrass Soc. Res. J. 7:877-881.

Richardson, M.D., and J.W. Boyd. 2001. Establishing Zoysia japonica from sprigs: Effects of topdressing and nitrogen fertility. HortScience 36:377-379. 